\title{
The Correlation of Serum NT-proBNP Levels of Hemorrhagic and Ischemic Lesions Detected with Diffusion MRI in Head Traumas
}

\author{
Kafa Travmalarında Difüzyon MR ile Tespit Edilen Hemorajik ve \\ Iskemik Lezyonlarn Serum NT-proBNP Düzeyleri ile Korelasyonu
}

\author{
Bekir AKGUN ${ }^{1}$, Fatih Serhat EROL ${ }^{2}$, Hanefi YILDIRIM ${ }^{3}$, Nevin ILHAN ${ }^{4}$, Metin KAPLAN ${ }^{2}$ \\ ${ }^{1}$ Yuksekova State Hospital, Department of Neurosurgery, Hakkari, Turkey \\ ${ }^{2}$ Firat University Hospital, Department of Neurosurgery, Elazig, Turkey \\ ${ }^{3}$ Firat University Hospital, Department of Radiology, Elazig, Turkey \\ ${ }^{4}$ Firat University Hospital, Department of Biochemistry, Elazig, Turkey
}

Corresponding Author: Bekir AKGUN / E-mail: bekirakgun@yahoo.com

\begin{abstract}
AIM: To evaluate the correlation between the dimensions of ischemic and hemorrhagic lesions detected by diffusion MRI and the changes in lesion dimensions with serum NT-proBNP levels in mild and moderate head trauma.

MATERIAL and METHODS: 30 patients were assessed in our study. A control group of 10 individuals with no trauma history was formed in order to establish normal serum NT-proBNP values. Patients underwent brain diffusion MRI 24 and 48 hours following admittance. Their plasma NT-proBNP levels were checked at the same stages.

RESULTS: The correlation between the values of 24th and 48th hour Intra-axial hemorrhage (IAHEM) and Intra-axial ischemia (IAISC) and the values of 24th and 48th hour NT-proBNP was established as statistically significant.

CONCLUSION: It was observed that the serum NT-proBNP values could be higher in patients with wide intra-axial lesion following head trauma than patients with smaller intra-axial lesions. In addition, the fact that it has been established that the serum NT-proBNP values of patients with increasing cerebral parenchymal lesion dimensions on the advancing hours after the trauma increase suggests that serum NTproBNP values may be significant in the follow-up of the dimensions of cerebral parenchymal damage.
\end{abstract}

KEYWORDS: Head injuries, NT-proBNP, Diffusion MRI, Ischemia, Hemorrhage

öz

AMAÇ: Hafif ve orta dereceli kafa travmalarında difüzyon MR da tespit edilen iskemik ve hemorajik lezyonların boyutları ve lezyon boyutlarındaki değişimler ile serum NT-proBNP düzeyleri arasındaki ilişkiyi değerlendirmek.

YÖNTEM ve GEREÇLER: Çalışmamızda kafa travmalı 30 hasta değerlendirildi. Travma öyküsü olmayan 10 kişilik kontrol grubu normal serum NT-proBNP değerlerini belirlemek için oluşturuldu. Hastalara yatışlarından itibaren 24. saatte ve 48. saatte beyin difüzyon MR çekildi. Aynı dönemlerde plazma NT-proBNP düzeyleri bakıldı.

BULGULAR: 24. ve 48. saat Intraaksiyal hemoraji (IAHEM) ve Intraaksiyal iskemi (IAISC) değerleri ile 24. ve 48. saat NT-proBNP değerleri arasındaki ilişki istatistiksel olarak anlamlı bulundu.

SONUÇ: Serum NT-proBNP değerlerinin kafa travmaları sonrası intraaksiyal lezyonu geniş olan hastalarda daha küçük intraaksiyal lezyonlulardan yüksek olabileceği izlendi. Ayrıca travmanın ilerleyen saatlerinde serebral parankimal lezyon boyutları artan hastalarda serum NT-proBNP değerlerinin de artmasının belirlenmesi, serum NT-proBNP değerlerinin serebral parankimal hasarın boyutlarının takibinde önemli olabileceğini düşündürmektedir.

ANAHTAR SÖZCÜKLER: Kafa travmaları, NT-proBNP, Difüzyon MRG, İskemi, Hemoraji

\section{INTRODUCTION}

Cerebral computerized tomography (CCT) immediately after head trauma is a commonly preferred method. CCT bears importance both in the fast evaluation of calvaria and cerebral parenchyma and the detection of cases requiring immediate surgical treatment (5).
Good structural imaging is possible with CCT. However, CCT can sometimes be normal but various neurological disorders may be present in patients, or CCT findings can fall short in being able to explain neurological manifestations $(5,18)$. Therefore, it is beneficial to view and evaluate functional and physiological properties in addition to structural imaging in such cases. Both structural and physiological evaluation is 
possible with MRI due to its ability to use various sequences and its feature of higher resolution (5). Besides, it is common that patients with lesions especially in deep white matter and brain stem following a head trauma are faced with worse prognoses and results. With a much higher sensitivity in evaluating these areas than CCT, MRI is an imaging system that can greatly contribute to identifying their prognoses functionally, and long-term results $(5,18)$.

Diffusion-weighted MRI has been proven to be valuable thanks to its ease of application as in its ability to obtain images in one minute without the need of contrast and to be diagnostic for numerous diseases. Diffusion-weighted imaging is highly sensitive to changes in microscopic movements of water molecules and is quite responsive in the distinction of cytotoxic and vasogenic edema, especially in acute cerebral ischemia. Parallel to this, it is significant in diagnosis, treatment, and prognosis prediction (18).

BNP is a neurohormone that is produced and secreted after the stretching of cardiac ventricles due to volume and pressure overload. In addition, it is a natriuretic, effective vasodilator factor and it is able to decrease the cerebral blood flow as a result of its systemic effects $(16,20,21)$. This neurohormone is secreted as preproBNP and then divided as N-Terminal proBNP and BNP by being enzymatically disrupted due to the stretching of ventricular myocytes. The active hormone showing effect in the body is BNP. However, it disappears in the blood in a very short time. Thus, testing the NT-proBNP that exists for longer in blood, is secreted in equal amounts at all hours of the day and night, is quickly identifiable and that is more stable is preferable (9).

The role of natriuretic peptides in acute trauma has not been widely studied. However, studies have demonstrated that BNP plasma concentration increases following head trauma $(20,21)$. Serum BNP levels following head trauma have frequently been studied in patients with severe head trauma and have been found to significantly increase intracranial pressure (20). In such patients, clinical picture is often accompanied by additional pathologies, such as hypoxia, hypotension, and multi-organ trauma. BNP values might be influenced by systemic factors. Therefore, we preferred patients with mild and moderate head trauma, especially isolated head trauma. We aimed to evaluate the correlation between the dimensions of ischemic and hemorrhagic (intraaxial/extra-axial) lesions and changes in the lesion dimensions identified by diffusion MRI in these patients with serum NTproBNP concentrations. Our main objective is to establish whether evaluation of serum NT-proBNP levels is effective in the follow-up of intra-cranial lesions after head trauma.

\section{MATERIAL and METHODS}

Our study was conducted at the Departments of Neurosurgery, Radiology and Biochemistry following the approval of the Faculty of Medicine Board of Ethics at our University.

In this study, 30 patients that were admitted to our Neurosurgery clinic between the dates of March 2009 and
March 2010 due to mild (GCS 14 or 15) and moderate (GCS 9-13) head trauma were evaluated. Of the patients, 20 were male and 10 were female. A 10-person voluntary control group that was comprised of 6 males and 4 females was formed in order to establish normal serum NT-proBNP values.

Patients underwent brain diffusion MRI at the $24^{\text {th }}$ and $48^{\text {th }}$ hours following their admittance and plasma NT-proBNP levels were checked at the same stages.

\section{Diffusion-Weighted Magnetic Resonance Imaging}

Brain diffusion-weighted Magnetic Resonance Imaging of the cases included in the study was obtained from the MRI unit of the Department of Radiology.

The study was conducted by utilizing 1.5T GE Sigma Highspeed Scanner Excite MR system (General Electric, Milwaukee, WI, USA). All the cases were prepared for the test in supine position, so as to be centered on brain coil. Patients and the relatives of the patients were informed about the rules they had to follow during the test. Communication with patients was done through an MRI-compatible headphones system during the test. At the time of imaging, patients were not applied any sedation.

Following the obtaining of 3-plane-localizer (pilot) images, b1000 weighted images were taken in the axial plane. The parameters used in the images are as follows:

${ }^{*}$ Diffusion Weighted Images (DWI) Matrix: 128x128, Number of Excitations (NEX): 1, Field of view FOV: $36 \times 36 \mathrm{~cm}$, slice thickness: $5 \mathrm{~mm}$, interslice gap: 0, diffusion direction: All directions, Repetition Time (TR): 8000 msn, Echo Time (TE): Minimum.

\section{Analysis of the Images}

The obtained diffusion-weighted images were evaluated at the workstation of the MRI system (Advantage Windows, 4, 2 software version, GE Medical Systems).

The volume of the pathology detected in diffusion-weighted imaging was established by multiplying the slice thickness and the plane. Volumes of the pathologies identified by DWI were evaluated in " $\mathrm{mm}^{3}$."

Pathologies identified by diffusion-weighted imaging were categorized as intra-axial ischemia (IAISC), intra-axial hemorrhage (IAHEM), and extra-axial hemorrhage (EAHEM). Infarctions in brain parenchyma were evaluated in "IAISC", contusions again in brain parenchyma and intra-cerebral hemorrhage in "IAHEM", and epidural, subdural, and subarachnoid hemorrhages in "EAHEM" categories.

\section{Biochemical Analyses}

$\mathrm{N}$-terminal proBNP test: $5 \mathrm{ml}$ blood specimens were taken from each patient after a period of fasting and collectively tested after storing in $-70^{\circ} \mathrm{C}$ after the serum was separated in centrifuge for 1 hour. Repeated freezing and thawing procedures were avoided. 
$\mathrm{N}$-terminal proBNP measurement was conducted by electrochemiluminescence immunoassay method quantitatively with an immunoanalysis tool with the compatible kit.

$\mathrm{N}$-terminal proBNP was tested by chemiluminescence method in Siemens IMMULITE 2000 (Flanders, NJ, 07836 USA).

The test was carried out by the ECLIA (electrochemiluminescence immunoassay) principle that utilizes the sandwich principle. The fundamental principle is the formation of luminescence by electrochemical reaction initiated via an application of voltage to electrodes following the electrode contact of magnetic microparticles, on the surface of which an antigen-antibody reaction occurs. Luminescence occurs as a result of radiant energy or a diffusion of light occurring when an electron is stimulated (ruthenium) or when it turns from a high energy level into a low energy level. First of all, antigen in the specimen (NT-proBNP) creates a sandwich complex with polyclonal NT-proBNP specific antibody labeled with biotinized polyclonal NTproBNP specific antibody and a ruthenium complex. This sandwich complex is then bound together as a result of biotin-streptavidin following the addition of streptavidin labeled magnetic microparticles. While the magnetic microparticles charged with immunocomplexes flow through current cells, they accumulate at a certain spot on the electrode with the effect of the magnet. They stay in that position for a short time. Later on, an already established amount of voltage is applied in order to commence the electrochemiluminescence reaction. The resulting diffusion of light is measured by a luminometer. When the reaction is complete, magnetic beads are released and taken away by washing with a washing solution. The results are obtained by calibration curve created with tool-specific two-point calibration and master curve specified with reactive barcode.

The obtained serum NT-proBNP values were assessed in terms of "pg/mL".

\section{Statistical Method}

While the findings obtained in the study were evaluated, SPSS (Statistical Package for Social Sciences) for Windows 17.0 software was utilized for statistical analysis. And while the study data were evaluated, a One Way Anova test was used for the comparison of definitive statistical methods (Average, Standard Deviation, Percentage) and Quantitative data, and in the case of more than two groups, for the intergroup comparison of parameters, and an LSD test was utilized to detect which group was causing the difference.

The results were evaluated at a $95 \%$ confidence interval and at a $\mathrm{p}<0.05$ significance level.

\section{RESULTS}

This study was conducted on a total of 30 cases, 10 of which were female (33.3\%) and 20 were male $(66.7 \%)$ aged between three and 89. The median age of the cases was 34.8 \pm 24.8 . The control group was comprised of a total of 10 cases, four of which were female (40\%) and six were male $(60 \%)$ aged between 16 and 75 . The median age of the control group was $35,3 \pm 17,4$.
The correlation between the $24^{\text {th }}$ hour IAISC values and the $24^{\text {th }}$ hour BNP values was found to be significant $(p<0.05)$. The correlation between the $48^{\text {th }}$ hour IAISC values and the $48^{\text {th }}$ hour BNP values was found to be significant $(p<0.05)$.

The correlation between the $24^{\text {th }}$ hour IAHEM values and the $24^{\text {th }}$ hour BNP values was found to be significant $(p<0.05)$. The correlation between the $48^{\text {th }}$ hour IAHEM values and the $48^{\text {th }}$ hour BNP values was found to be significant $(p<0.05)$.

A significant correlation was not found between the $24^{\text {th }}$ hour EAHEM values and the $24^{\text {th }}$ hour BNP values ( $\left.p>0.05\right)$. A significant correlation was not found between the $48^{\text {th }}$ hour EAHEM values and the $48^{\text {th }}$ hour BNP values ( $\left.p>0.05\right)$.

The characteristics, $24^{\text {th }}$ and $48^{\text {th }}$ hour GCS and NT-proBNP values of patients are given in Table $\mathrm{I}$, and $24^{\text {th }}$ and $48^{\text {th }}$ hour Diffusion MRI findings are given in Table II. Control group patients' NT-proBNP values are shown in Table III.

The distribution of pathologies identified by the $24^{\text {th }}$ hour DWI according to the $24^{\text {th }}$ hour NT-proBNP values are given in Figure 1, and the distribution of pathologies identified by the $48^{\text {th }}$ hour DWI according to the $48^{\text {th }}$ hour NT-proBNP values are shown in Figure 2.

\section{DISCUSSION}

Identification of the amount and characteristics of brain damage in the shortest time possible following head trauma has been demonstrated to be important in estimating its results in the long run and the consequences (19). Numerous researchers, in recent years, have been emphasizing the role of brain injuries in the formation of neurocognitive deficits and behavioral abnormalities. As a result, interest in various advanced imaging methods for patients with head trauma has increased (11).

CCT is quite beneficial for the evaluation of intra-cranial hemorrhage, cerebral edema, midline shift, and calvarial fractures. Often damaged gray-white matter interface,

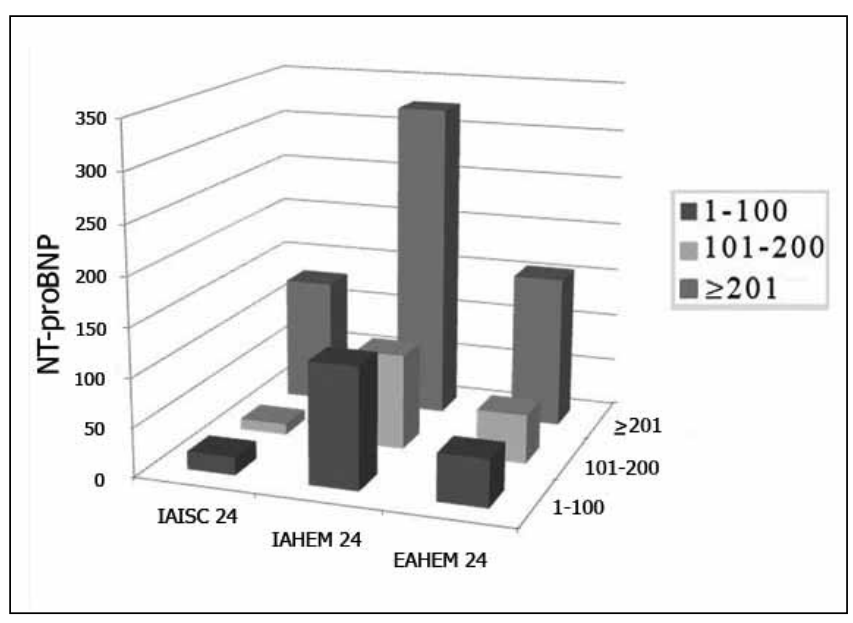

Figure 1: The distribution of pathologies identified by the $24^{\text {th }}$ hour Diffusion Weighted Imaging according to the $24^{\text {th }}$ hour NTproBNP values. 
Table I: The Characteristics, $24^{\text {th }}$ and $48^{\text {th }}$ Hour GCS and NT-proBNP Values of the Patients

\begin{tabular}{|c|c|c|c|c|c|c|}
\hline Order & Age & Gender & GCS 24 & GCS 48 & NT-proBNP 24 (pg/mL) & NT-proBNP 48 (pg/mL) \\
\hline 1 & 5 & $M$ & 13 & 14 & 179 & 72.4 \\
\hline 2 & 15 & $M$ & 15 & 15 & 255 & 69.4 \\
\hline 3 & 4 & M & 15 & 15 & 84.3 & 42 \\
\hline 4 & 12 & M & 10 & 10 & 67.8 & 205 \\
\hline 5 & 17 & $\mathrm{~F}$ & 15 & 15 & 89.7 & 30.5 \\
\hline 6 & 5 & M & 14 & 15 & 118 & 51.4 \\
\hline 7 & 11 & M & 10 & 12 & 143 & 53.2 \\
\hline 8 & 19 & M & 15 & 15 & 97.5 & 57.7 \\
\hline 9 & 3 & $\mathrm{~F}$ & 9 & 10 & 1402 & 732 \\
\hline 10 & 9 & M & 10 & 11 & 174 & 22.3 \\
\hline 11 & 6 & $\mathrm{~F}$ & 14 & 15 & 218 & 146 \\
\hline 12 & 39 & $\mathrm{~F}$ & 15 & 15 & 176 & 44 \\
\hline 13 & 25 & $M$ & 15 & 15 & 117 & 74.7 \\
\hline 14 & 31 & $M$ & 14 & 15 & 31.4 & 22 \\
\hline 15 & 40 & $M$ & 15 & 15 & 46.5 & 54.3 \\
\hline 16 & 27 & $\mathrm{~F}$ & 15 & 15 & 132 & 131 \\
\hline 17 & 26 & $\mathrm{~F}$ & 14 & 14 & 71.2 & 115 \\
\hline 18 & 38 & $M$ & 11 & 13 & 64.8 & 36 \\
\hline 19 & 22 & $M$ & 15 & 14 & 26.6 & 49.3 \\
\hline 20 & 44 & $\mathrm{~F}$ & 14 & 14 & 281 & 133 \\
\hline 21 & 62 & $\mathrm{~F}$ & 15 & 15 & 144 & 115 \\
\hline 22 & 45 & $M$ & 15 & 15 & 112 & 163 \\
\hline 23 & 64 & $\mathrm{~F}$ & 14 & 15 & 509 & 339 \\
\hline 24 & 66 & $\mathrm{~F}$ & 15 & 15 & 450 & 593 \\
\hline 25 & 66 & $M$ & 14 & 15 & 277 & 143 \\
\hline 26 & 55 & $M$ & 15 & 14 & 55.6 & 270 \\
\hline 27 & 72 & $M$ & 14 & 14 & 1315 & 1886 \\
\hline 28 & 69 & $M$ & 12 & 13 & 706 & 201 \\
\hline 29 & 89 & $M$ & 12 & 12 & 468 & 586 \\
\hline 30 & 58 & $M$ & 14 & 14 & 51 & 88.2 \\
\hline
\end{tabular}

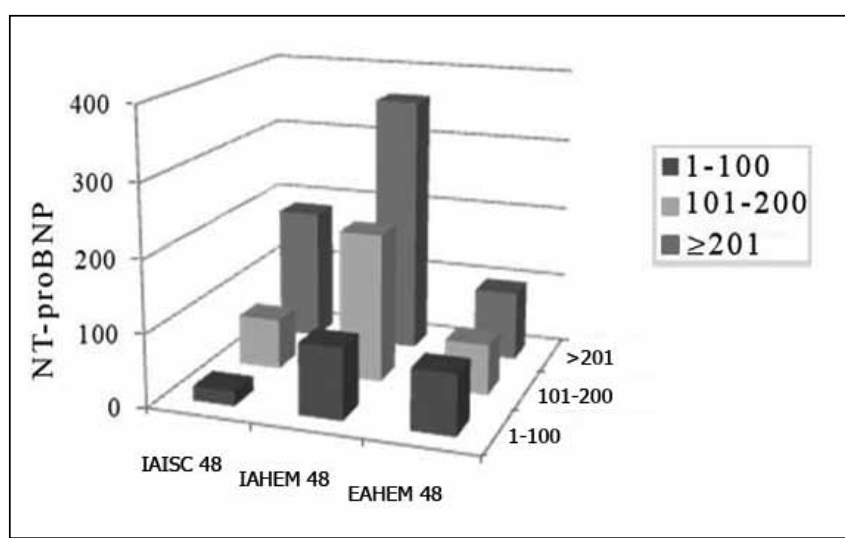

Figure 2: The distribution of pathologies identified by the $48^{\text {th }}$ hour Diffusion Weighted Imaging according to the $48^{\text {th }}$ hour NTproBNP values. corpus callosum, deep white matter, periventricular areas, hippocampal area, and brain stem are better evaluated with MRI than CCT. For this reason, the use of MRI shortly after CCT in head trauma or in the follow-up of the patient on the proceeding days has become increasingly preferable (5).

Recently, Diffusion-weighted MRI was demonstrated to be very valuable in the evaluation following head trauma due to its ease of application and its diagnostic characteristic for many diseases (18). Although it is more common to observe cerebral ischemic lesions and findings belonging to these lesions in severe head trauma, cerebral ischemic lesions accompanying the trauma may also develop in mild and moderate head trauma. The fact that CCT cannot display acute ischemic lesions, especially their dimensions, and that Diffusion-weighted MRI is very valuable in this respect 
Table II: $24^{\text {th }}$ and $48^{\text {th }}$ Hour Diffusion MRI Findings of the Patients

\begin{tabular}{|c|c|c|c|c|c|c|}
\hline Order & IAISC $24\left(\mathrm{~mm}^{3}\right)$ & IAISC $48\left(\mathrm{~mm}^{3}\right)$ & IAHEM $24\left(\mathrm{~mm}^{3}\right)$ & IAHEM $48\left(\mathrm{~mm}^{3}\right)$ & EAHEM $24\left(\mathrm{~mm}^{3}\right)$ & EAHEM $48\left(\mathrm{~mm}^{3}\right)$ \\
\hline 1 & 100 & 100 & 0 & 0 & 220 & 220 \\
\hline 2 & 0 & 0 & 0 & 0 & 280 & 260 \\
\hline 3 & 0 & 0 & 0 & 0 & 190 & 190 \\
\hline 4 & 160 & 160 & 180 & 240 & 0 & 0 \\
\hline 5 & 0 & 0 & 0 & 0 & 0 & 0 \\
\hline 6 & 0 & 0 & 0 & 0 & 0 & 0 \\
\hline 7 & 0 & 0 & 200 & 180 & 0 & 0 \\
\hline 8 & 100 & 100 & 180 & 180 & 210 & 210 \\
\hline 9 & 560 & 560 & 200 & 200 & 0 & 0 \\
\hline 10 & 0 & 0 & 210 & 200 & 0 & 0 \\
\hline 11 & 0 & 0 & 0 & 0 & 330 & 330 \\
\hline 12 & 0 & 0 & 0 & 0 & 0 & 0 \\
\hline 13 & 0 & 0 & 190 & 190 & 230 & 230 \\
\hline 14 & 100 & 100 & 0 & 0 & 0 & 0 \\
\hline 15 & 0 & 0 & 140 & 170 & 130 & 130 \\
\hline 16 & 0 & 0 & 0 & 0 & 0 & 0 \\
\hline 17 & 140 & 140 & 180 & 200 & 0 & 0 \\
\hline 18 & 0 & 0 & 180 & 180 & 0 & 0 \\
\hline 19 & 0 & 0 & 120 & 160 & 0 & 0 \\
\hline 20 & 0 & 0 & 460 & 460 & 180 & 160 \\
\hline 21 & 150 & 150 & 0 & 0 & 0 & 0 \\
\hline 22 & 0 & 0 & 280 & 310 & 0 & 0 \\
\hline 23 & 0 & 0 & 280 & 300 & 390 & 390 \\
\hline 24 & 260 & 290 & 190 & 200 & 0 & 0 \\
\hline 25 & 200 & 200 & 470 & 470 & 0 & 0 \\
\hline 26 & 180 & 180 & 190 & 320 & 0 & 0 \\
\hline 27 & 0 & 0 & 870 & 870 & 380 & 380 \\
\hline 28 & 0 & 0 & 780 & 750 & 0 & 0 \\
\hline 29 & 270 & 290 & 0 & 0 & 0 & 0 \\
\hline 30 & 0 & 0 & 190 & 210 & 0 & 0 \\
\hline
\end{tabular}

Table III: The Characteristics and NT-proBNP Values of Control Group Patients

\begin{tabular}{|l|c|c|c|}
\hline Order & Age & Gender & NT-proBNP value $(\mathrm{pg} / \mathrm{mL})$ \\
\hline Control 1 & 16 & $\mathrm{~F}$ & $<20$ \\
\hline Control 2 & 18 & $\mathrm{M}$ & $<20$ \\
\hline Control 3 & 19 & $\mathrm{~F}$ & $<20$ \\
\hline Control 4 & 30 & $\mathrm{M}$ & 24 \\
\hline Control 5 & 32 & $\mathrm{~F}$ & 37 \\
\hline Control 6 & 35 & $\mathrm{M}$ & 21.9 \\
\hline Control 7 & 40 & $\mathrm{M}$ & $<20$ \\
\hline Control 8 & 42 & $\mathrm{~F}$ & 33.6 \\
\hline Control 9 & 46 & $\mathrm{~F}$ & 39.2 \\
\hline Control 10 & 75 & & 45.7 \\
\hline
\end{tabular}


were the fundamental reasons for our preferring Diffusionweighted MRI in this study. In addition, the fact that it has a shorter imaging time when compared with other MRI sequences and applications was a significant advantage we gained by choosing Diffusion-weighted MRI since it is difficult for the patients to adjust to MRI device in the early stages following trauma. The most advanced imaging method that would let us obtain such vast information in such a short time was Diffusion-weighted MRI.

Two types of edema have been defined in live tissues. Cytotoxic edema is generally a manifestation of irreversible cell damage, especially acute infarct. However, vasogenic edema is observed more in reversible pathologic processes. Increased interstitial fluid is associated with vasogenic edema and is the cause of increased diffusion. Whereas, in cytotoxic edema, intracellular fluid increases and decreased diffusion are observed. This means that there exists diffusion restriction in acute ischemia $(3,13,18)$. So, we can define the pathophysiology of ischemia thanks to diffusion MRI. As a result, we can evaluate both hemorrhagic and ischemic lesions following an imaging with diffusion MRI. In order for this study to suit its objective, the dimensions of cerebral parenchymal damage (ischemic and/or hemorrhagic) had to be estimated thoroughly. For this reason, without settling for CCT findings in order to present the literature with the right information, evaluation was conducted with Diffusion MRI that gives more detailed information than CCT of lesions and their localization where CCT was insufficient.

When the pressure by blood on the heart wall increases and stretches the ventricle walls, BNP is synthesized by the ventricular muscle and its level increases $(15,17)$.

A large molecule, preproBNP, is secreted first from the muscles on the heart wall into the cell. This large molecule is disrupted into two within the cell. One of the pieces is proBNP. When proBNP is secreted into the blood when the heart is stretched, it is again divided into two distinct structures as NT-proBNP and BNP. The active hormone that shows effect in the body is BNP. However, as it disappears from the blood in a very short time, testing the NT-proBNP level would produce much more reliable results $(6,12)$. We also conducted our study by testing the NT-proBNP levels.

BNP manifests its effect by encouraging natriuresis and diuresis, causing vasodilatation, and suppressing the renninangiotensin-aldosterone system $(1,4,8)$. It decreases blood pressure and plasma volume. And as a result of this, it also decreases cerebral blood flow (20).

Recent studies have begun to focus on the significance of BNP on neurology and neurosurgery patients. Demonstration of the increase in serum NT-proBNP levels as the infarct area grows following acute ischemic stroke suggested that the brain infarct area or neuronal injury areas might be the potential sources of BNP (10). In addition, BNP plasma concentrations were associated with hyponatremia in aneurysmal subarachnoid bleeding, which is a significant problem in neurosurgery practice. In particular, serum BNP levels were shown to progressively increase in patients that develop late ischemic deficits associated with vasospasm $(16,20)$.

There is a limited number of studies on the role of $\mathrm{N}$-terminal proBNP in head trauma. However, studies show that BNP plasma concentration increases after head trauma. BNP (NTproBNP) concentrations increase more, especially in patients with high intra-cranial pressure $(20,21)$.

Serum ANP and BNP levels were reported to significantly increase in patients with focal brain edema (7). That the natriuretic peptides have regulatory roles in brain fluid and electrolyte content has also been shown in various animal experiments and particularly its intra-cranial pressure decreasing and cerebral antiedemic effects have been reported (14).

Serum BNP and/or NT-proBNP levels following head trauma have been frequently studied in cases that were being followed up due to severe head trauma, had complex pathologies concomitantly, with significantly high intra-cranial pressure (20). In such patients, such respiratory and circulation problems can generally accompany the clinical picture. Considering the serum BNP values may be influenced by systemic factors, it should be kept in mind that the additional pathologies of patients with severe head trauma may also affect serum BNP levels in degrees that show differences from patient to patient. For this reason, we preferred patients that presented due to mild and moderate head trauma, and especially isolated head trauma, in our study in order to better evaluate whether there is a relation between ischemic and hemorrhagic lesions detected by diffusion MRI and serum NT-proBNP concentrations. In addition, once again when the literature is assessed, it has been reported that serum BNP levels in cases with intra-cranial lesion following head traumas were significantly higher compared with cases that did not have intra-cranial lesions (2). However, we have yet to find a study that evaluates whether serum NT-proBNP values are affected by the dimensions of the injured tissue or from the changes in the dimensions. In line with our study, whether a correlation exists between the dimensions of the injured tissue after head trauma and the changes in the dimensions and serum NT-proBNP values was also under evaluation.

According to the data obtained in our study, the correlation between $24^{\text {th }}$ and $48^{\text {th }}$ hour IAISC and IAHEM and $24^{\text {th }}$ and $48^{\text {th }}$ hour BNP values after mild and moderate head trauma were found to be significant. Also, in patients with extraaxial lesion, serum NT-proBNP values were higher than the normal values. Still, a statistically significant relation was not established between $24^{\text {th }}$ and $48^{\text {th }}$ hour EAHEM values and $24^{\text {th }}$ and $48^{\text {th }}$ hour BNP values. As the number of patients with only extra-axial hemorrhage without the accompanying intra-axial pathology is not sufficient to provide any results, it would not be right to indicate the exact effect of extra-axial hemorrhage on NT-proBNP values. Besides, since such lesions as parenchymal edema and ischemia significantly accompany 
in patients with extra-axial hemorrhage like subdural hematoma, it is not much of a possibility to be able to make the distinction of pathology acting on serum NT-proBNP values for these patients. Hence, we believe that examination of the changes in diffusion MR findings at different hours and serum NT-proBNP values of patients with intra-axial lesions following mild and moderate head trauma would be more enlightening on the relation between parenchymal injury and BNP levels.

When evaluated, the diffusion MRI $24^{\text {th }}$ hour and $48^{\text {th }}$ hour findings, serum NT-proBNP levels of patients that did not suffer an increase in parenchymal damage was established to decrease at the $48^{\text {th }}$ hour compared with the $24^{\text {th }}$ hour. Only one patient demonstrated a slight increase in serum NT-proBNP levels without a change in the $24^{\text {th }}$ hour and $48^{\text {th }}$ hour diffusion MRI findings. When both our study and the literature is evaluated, decrease in BNP values in the posttraumatic period may be influenced by BNP half-life and antiedema treatment complexes given following head trauma provided an impairment does not exist in the clinical picture of the patient. We did not apply an anti-edema treatment on patients with GCS 15. However, treatment doses for cases with a GCS value less than 15 were adjusted according to the clinical picture of the patient.

In this study, there are 7 patients (by 4,15,17,22,24,29,30 numbered patients) who have not shown a worsening in GCS at $24^{\text {th }}$ and $48^{\text {th }}$ hours, but the levels of serum NT-proBNP values have increased. Besides, table 2 shows that these patients have increase in cerebral parenchymal lesion dimensions. A very important issue that stands out is that NT-proBNP levels also increase at the $48^{\text {th }}$ hour compared with the $24^{\text {th }}$ hour in all patients that were observed to have an increase in intra-axial tissue damage at the $48^{\text {th }}$ hour compared with the $24^{\text {th }}$ hour (with or without worsening in GCS). Our study shows serum NT-proBNP value may increase as a result of parenchymal lesion growth. When Table 1 and 2 was evaluated together, little amounts of growth in lesion's dimension in diffusion $\mathrm{MRI}$, can increase the serum NT-proBNP value. In our opinion, Diffusion-weighted MRI is not insufficient for parenchymal lesion detection. Maybe even a little increase in the lesion's dimension can cause adjacent tissue influence by cellular interaction. At the result it can increase the level of serum NT-proBNP value. These data show that, as the volume of cerebral parenchymal tissue injured at the hours and on the days following the head trauma increases, with even a little increase in the lesion's dimension, serum NT-proBNP levels may increase as well. These findings support the idea that BNP that is secreted primarily from cardiac ventricles can also be secreted from neuronal injury areas, moreover affected adjacent tissues, following cranial damage.

\section{CONCLUSION}

Consequently, serum NT-proBNP values have also been observed to increase following mild and moderate head traumas when compared with normal values. In our study, a statistically significant relationship was established between the rise in serum NT-proBNP values and intra-axial ischemic and intra-axial hemorrhagic lesion dimensions. Also, in patients with extra-axial lesions, serum NT-proBNP values were higher than the normal values; however, our evaluation established a correlation, in particular, between intra-axial ischemia and/or hemorrhage dimensions (amount of the affected intra-axial tissue) and serum NT-proBNP values following head trauma. These findings support the idea that BNP can also be primarily secreted from neuronal injury areas. It was concluded with this study that serum NT-proBNP levels of patients with a large intra-axial lesion could be higher than in patients with smaller intra-axial lesion. Additionally, it was observed in our study that the serum NT-proBNP levels might also increase in such cases as hemorrhage increase, edema, or increase in ischemia in cerebral parenchyma tissue. Successful lesion dimension measurement is necessary for proving our results. So new studies about this issue using other advanced neuroradiological imaging technics can be performed. If supported with similar studies, NT-proBNP could become a marker to be used in the assessment and follow-up of the increase in size of cerebral parenchymal lesions following head trauma.

\section{REFERENCES}

1. Baughman $\mathrm{KL}$ : B-Type natriuretic peptide - a window to the heart. N Engl J Med 347:158-159, 2002

2. Cevik Y, Durukan P, Erol FS, Yıldız M, Ilhan N, Serhatlıoğlu $S$ : Diagnostic value of bedside brain natriuretic peptide measurement in patients with head trauma. Akademik Acil Tıp Dergisi 9:21-25, 2010

3. Chong J, Lu D, Aragao F, Singer MB, Schonewille WJ, Silvers A, Tuhrim S, Atlas SW: Diffusion-weighted MR of acute cerebral infarction: comparison of data processing methods. Am J Neuroradiol 19:1733-1739, 1998

4. Cole CD, Gottfried ON, Liu JK, Couldwell WT: Hyponatremia in the neurosurgical patient: Diagnosis and management. Neurosurg Focus 16:1-10, 2004

5. Coles JP: Imaging after brain injury. Br J Anaesth 99:49-60, 2007

6. Friedl W, Mair J, Thomas S, Pichler M, Puschendorf B: Natriuretic peptides and cyclic guanosine $3^{\prime}, 5^{\prime}$-monophosphate in asymptomatic and symptomatic left ventricular dysfunction. Heart 76:129-136, 1996

7. Fukui $S$, Katoh $H$, Tsuzuki $N$, Ishihara $S$, Otani $N$, Ooigawa $H$, Toyooka T, Ohnuki A, Miyazawa T, Nawashiro H, Shima K: Focal brain edema and natriuretic peptides in patients with subarachnoid hemorrhage. J Clin Neurosci 11:507-511, 2004

8. Levin ER, Gardner DG, Samson WK: Natriuretic peptides. N Engl J Med 339:321-328, 1998

9. Murray H, Cload B, Collier CP, Sivilotti ML: Potential impact of $\mathrm{N}$-terminal pro-BNP testing on the emergency department evaluation of acute dyspnea. Can J Emerg Med 8:251-258, 2006

10. Oppenheimer SM, Lima J: Neurology and the heart. J Neurol Neurosurg Psychiatry 64:289-297, 1998 
11. Provenzale JM: Imaging of traumatic brain injury: A review of the recent medical literature. AJR 194:16-19, 2010

12. Raymond I, Groenning BA, Hildebrandt PR, Nilsson JC, Baumann M, Trawinski J, Pedersen F: The influence of age, sex and other variables on the plasma level of $\mathrm{N}$-terminal pro brain natriuretic peptide in a large sample of the general population. Heart 89:745-751, 2003

13. Romero JM, Schaefer PW, Grant PE, Becerra L, Gonzalez RG: Diffusion MR imaging of acute ischemic stroke. Neuroimaging Clin North Am 12:35-53, 2002

14. Rosenberg GA, Estrada EY: Atrial natriuretic peptide blocks hemorrhagic brain edema after 4-hour delay in rats. Stroke 26:874-877, 1995

15. Stein BC, Levin RI: Natriuretic peptides: Physiology, therapeutic potential and risk stratification in ischemic heart disease. Am Heart J 135:914-923, 1998

16. Stewart D, Waxman K, Brown CA, Schuster R, Schuster L, Hvingelby EM, Kam K, Becerra S: B-type natriuretic peptide levels may be elevated in the critically injured trauma patient without congestive heart failure. J Trauma 63:747-750, 2007
17. Suga S, Nakao K, Hosoda K, Mukoyama M, Ogawa Y, Shirakami G, Arai H, Saito Y, Kambayashi Y, Inouye K: Receptor selectivity of natriuretic peptide family, atrial natriuretic peptide, brain natriuretic peptide, and C-type natriuretic peptide. Endocrinology 130:229-239, 1992

18. Sundgren PC, Reinstrup P, Romner B, Holtas S, Maly P: Value of conventional, and diffusion-and perfusion weighted MRI in the management of patients with unclear cerebral pathology, admitted to the intensive care unit. Neuroradiology 44:674680,2002

19. Suskauer SJ, Huisman TA: Neuroimaging in pediatric traumatic brain injury: Current and future predictors of functional outcome. Dev Disabil Res Rev 15:117-123, 2009

20. Sviri GE, Feinsod M, Soustiel JF: Brain natriuretic peptide and cerebral vasospasm in subarachnoid hemorrhage. Clinical and TCD correlations. Stroke 31:118-122, 2000

21. Sviri GE, Soustiel JF, Zaaroor M: Alteration in brain natriusretic peptide (BNP) plasma concentration following severe traumatic brain injury. Acta Neurochir (Wien) 148:529-533, 2006 